\title{
Clinical significance of pharmacogenomic studies in tardive dyskinesia associated with patients with psychiatric disorders
}

This article was published in the following Dove Press journal:

Pharmacogenomics and Personalized Medicine

13 October 2014

Number of times this article has been viewed

\author{
Florence CF Chang \\ Victor SC Fung \\ Movement Disorders Unit, \\ Department of Neurology, \\ Westmead Hospital, Sydney \\ Medical School, University of \\ Sydney, Sydney, NSW, Australia
}

Correspondence: Victor Fung Movement Disorders Unit, Department of Neurology, Level I, Block AB, Westmead Hospital, Corner Darcy and Hawkesbury Road, Westmead, NSW 2145, Australia

Tel +6I 298456793

Fax +6I 296356684

Email vscfung@ozemail.com.au

\begin{abstract}
Pharmacogenomics is the study of the effects of genetic polymorphisms on medication pharmacokinetics and pharmacodynamics. It offers advantages in predicting drug efficacy and/or toxicity and has already changed clinical practice in many fields of medicine. Tardive dyskinesia (TD) is a movement disorder that rarely remits and poses significant social stigma and physical discomfort for the patient. Pharmacokinetic studies show an association between cytochrome P450 enzyme-determined poor metabolizer status and elevated serum antipsychotic and metabolite levels. However, few prospective studies have shown this to correlate with the occurrence of TD. Many retrospective, case-control and cross-sectional studies have examined the association of cytochrome P450 enzyme, dopamine (receptor, metabolizer and transporter), serotonin (receptor and transporter), and oxidative stress enzyme gene polymorphisms with the occurrence and severity of TD. These studies have produced conflicting and confusing results secondary to heterogeneous inclusion criteria and other patient characteristics that also act as confounding factors. This paper aims to review and summarize the pharmacogenetic findings in antipsychotic-associated TD and assess its clinical significance for psychiatry patients. In addition, we hope to provide insight into areas that need further research.
\end{abstract}

Keywords: pharmacogenomics, tardive dyskinesia, cytochrome P450, pharmacogenetic, schizophrenia

\section{Introduction}

Pharmacogenomics is the study of the effect of genetic polymorphisms on medication pharmacokinetics and pharmacodynamics. This has predictive implications on the medication efficacy, toxicity or side effect profile for the individual. It was first described in 1999 by Evans et al $^{1}$ who proposed a prediction of medication response can be made from an individual's genetic constitution. Genetic polymorphisms of drug metabolizing enzymes, drug transporter and drug target receptor genes have each been implicated. Pharmacogenomics has been used in numerous medical specialties. For example, testing for thiopurine methyltransferase metabolizer status prior to azathioprine commencement can predict and avoid life-threatening myelosuppression. ${ }^{2}$ Pharmacogenomics offers an advantage in predicting drug efficacy and/or toxicity, hence provides cost-effectiveness, and has already changed clinical practice in the field of oncology, hematology, and immunology.

Tardive dyskinesia (TD) is a movement disorder that rarely remits ${ }^{3}$ and poses significant social stigma and physical discomfort for the patient. It occurs following the initiation, administration or withdrawal of a dopaminergic antagonist or indirect dopaminergic inhibitor such as a selective serotonergic reuptake inhibitor. ${ }^{4}$ 
TD comprises of non-rhythmic, repetitive stereotyped tongue protrusion, lip smacking, chewing and smacking movements, and may also involve the limbs and trunk. ${ }^{5}$ The prevalence of TD is between $9.3 \%-39.7 \%$ of patients on dopamine antagonists. ${ }^{6-8}$ The estimated incidence is $2.9 \%$ and 5\%-7.7\% per year for second-generation (atypical) and first-generation (typical) antipsychotics, respectively. ${ }^{9}$ Several studies found varying prevalence between different ethnicities. ${ }^{10,11}$ African ethnicity is associated with higher risk of TD and less likelihood of improvement in a number of studies, even after correcting for antipsychotic dose. ${ }^{12,13}$ Familial TD has been reported, ${ }^{14,15}$ even with correction for antipsychotic dose and patient age, ${ }^{16}$ further implicating genetic contribution to this condition. This has led to investigations into the contribution of genetic polymorphism in patients with TD following antipsychotic exposure.

The exact pathophysiology of TD to date is unclear. A number of hypotheses have been proposed over the decades. Genetic predisposition is suggested by reports of familial TD. However, environmental influence and increased susceptibility due to the effects of aging such as accumulated oxidative stress could explain the increased prevalence of TD with older age. In the 1990s, various studies found polymorphisms associated with poor metabolizer status for the cytochrome 2D6 (CYP2D6) gene are associated with TD. ${ }^{17}$ This enzyme metabolizes all the first-generation (typical) antipsychotics as well as second-generation antipsychotics such as aripiprazole, risperidone and paliperidone. ${ }^{18}$ However, more recent studies and meta-analysis have found no association between TD and CYP2D6 polymorphisms. Other case-control and longitudinal studies examined the role of dopamine receptor D2 and D3 subtypes in TD and found it is associated with TD in Caucasian, Chinese and Jewish populations. ${ }^{19-21}$ Studies examining dopamine receptor subtypes from animal models and human observations of TD, showing dopamine receptor hypersensitivity following prolonged dopaminergic antagonist exposure, are another hypothesis for TD. However this hypothesis does not explain the persistence of TD despite cessation of the dopaminergic antagonist. An alternative hypothesis of neuronal toxicity through oxidative stress was proposed in the 1990s. In vitro studies that supported this theory found haloperidol produced oxidative stress, with subsequent neuronal death in vitro. ${ }^{22,23}$ These neurons are rescued by the addition of vitamin $\mathrm{E}^{24}$ and this led to a clinical study which found vitamin E reduces TD. ${ }^{25}$ Subsequent pharmacogenomic studies examined the various genes involved in oxidative stress for their role in TD. Genes that encode the oxidative stress pathway enzymes and antioxidants may alter the production of free radicals. Some examples of oxidative pathway enzymes examined for their role in TD are glutathione-S-transferase, manganese superoxide dismutase, nitric oxide synthase, and quinone oxidoreductase.

In the last 14 years, novel genetic polymorphisms in the alpha-1A adrenergic receptor (ADRA1A), ${ }^{26}$ G-protein signaling regulator (RGS9), ${ }^{27}$ solute family carrier 18 (SLC18A2), ${ }^{28}$ nitric oxide synthase 3 (NOS3), ${ }^{29}$ cannabinoid receptor (CNR1), ${ }^{30}$ and beta-arrestin (ARRB2), ${ }^{31}$ have been associated with TD in single studies. Other genes have polymorphisms associated with reduced risk of TD. These are: manganese superoxide dismutase gene (MnSOD), ${ }^{32} \mathrm{NOS} 3,{ }^{33} \mathrm{CYP} 3 \mathrm{~A} 5$, serotonin receptor $2 \mathrm{~A}$ (5-HT2A) and dopamine receptor 4 (DRD4). Recent observational studies investigating the role of dopamine receptor subtypes, serotonin receptor subtypes, CYP2D6, and CYP1A2 in TD, have yielded conflicting results. This may be explained by confounding factors such as a small sample size, retrospective study design, heterogeneous ethnic cohort, heterogeneous antipsychotic use, age, smoking status, and concurrent medication or alcohol use. ${ }^{34}$ Further complicating the matter, meta-analysis and genome-wide association studies have found conflicting results for dopamine receptor and serotonergic receptor gene polymorphisms. Although many pharmacokinetic studies have demonstrated elevated serum antipsychotic levels in patients who are poor metabolizers according to cytochrome enzyme status, they did not find a correlation between TD and serum antipsychotic levels. This paper aims to review and summarize the pharmacogenetic findings in antipsychoticassociated TD and assess its clinical significance for psychiatry patients. In addition, we hope to provide insight into areas that need further research.

\section{Method}

The literature search was performed through PubMed and OVID by entering the following keywords: "(pharmacogenetic) OR (cytochrome P*) AND (tardive dyskinesiaTD)". Searches were limited to English language articles and publications published before March 2014.

\section{Results CYP2D6}

CYP2D6 is the main cytochrome enzyme responsible for the metabolism of all the typical and many atypical antipsychotic medications such as aripiprazole, risperidone and paliperidone $^{18}$ (Table 1). The prevalence of poor metabolizer status varies across different ethnicities (Table 2). CYP2D6 poor metabolizer status is found in $8 \%$ of Caucasian and 
Table I Effect of cytochrome enzyme metabolism state on serum antipsychotic level and its association with tardive dyskinesia

\begin{tabular}{|c|c|c|c|c|}
\hline $\begin{array}{l}\text { Cytochrome } \\
\text { enzyme }\end{array}$ & Antipsychotic & $\begin{array}{l}\text { Serum antipsychotic level } \\
\text { PM compared to EM }\end{array}$ & $\begin{array}{l}\text { Serum antipsychotic level } \\
\text { UM compared to EM }\end{array}$ & $\begin{array}{l}\text { Metabolizer group } \\
\text { associated with TD }\end{array}$ \\
\hline \multirow[t]{9}{*}{ CYP2D6 } & Aripiprazole & $60 \%$ higher serum level ${ }^{46}, 1.6$ fold & & NSD \\
\hline & & increase in active metabolite $e^{46,47}$ & & \\
\hline & Clozapine & No difference $e^{47,156-158}$ & No difference ${ }^{157,158}$ & NSD \\
\hline & Haloperidol & $\begin{array}{l}\text { Increased serum haloperidol and } \\
\text { metabolite levels }{ }^{38-42,44,45,159}\end{array}$ & & No association with TD ${ }^{44}$ \\
\hline & Risperidone & Increased serum risperidone $e^{42,48}$ & & No association with TD ${ }^{58,59}$ \\
\hline & Zuclopenthixol & I.6-2 fold increased serum level ${ }^{49-52}$ & & $\begin{array}{l}\text { Conflicting results. PM associated } \\
\text { with TD in one study, }{ }^{51} \text { another } \\
\text { found no association with TD }{ }^{58,59}\end{array}$ \\
\hline & Perphenazine & $2.9-4$ fold increased serum level ${ }^{54,160}$ & & No association with TD ${ }^{58,59}$ \\
\hline & Thioridazine & I.8-4.5 fold increased serum level ${ }^{55-57}$ & & NSD \\
\hline & Olanzapine & No difference ${ }^{\mid 61}$ & & No association with TD ${ }^{58,59}$ \\
\hline CYPIA2 & Olanzapine & No difference ${ }^{\mid 61}$ & & No association with TD ${ }^{58,59}$ \\
\hline \multirow[t]{5}{*}{ CYP3A4 } & Thioridazine & I.8-4.5 fold increase serum level| ${ }^{55-57}$ & & NSD \\
\hline & Aripiprazole & I.5-1.8 fold increase in serum level, & & NSD \\
\hline & & I.6 fold increase in active metabolite ${ }^{46}$ & & \\
\hline & Ziprasidone & NSD & & NSD \\
\hline & Olanzapine & NSD & $\begin{array}{l}\text { Subtherapeutic serum } \\
\text { olanzapine level| } 162\end{array}$ & NSD \\
\hline
\end{tabular}

Abbreviations: PM, poor metabolizer; EM, extensive metabolizer; UM, ultrafast metabolizer; TD, tardive dyskinesia; NSD, no studies done.

African cohorts, $6 \%-10 \%$ of Asian cohorts, but is relatively rare in Japanese and Korean cohorts. ${ }^{35-38}$

CYP2D6 poor metabolizers have a 1.5- to 2-fold increase in serum levels of haloperidol and its metabolite, ${ }^{39-47}$ aripiprazole ${ }^{48}$ and its active metabolite, ${ }^{48,49}$ risperidone, ${ }^{44,50}$ and zuclopenthixol. ${ }^{51-54}$ Serum perphenazine and thioridazine levels are increased 2- to 4-fold in poor metabolizers compared to extensive metabolizers. ${ }^{55-59}$ However, pharmacokinetic studies have not found higher incidences of TD in poor metabolizers for other antipsychotics. ${ }^{46,60,61}$ One study found zuclopenthixol-poor metabolizers are more likely to develop TD (odds ratio $[\mathrm{OR}]=1.7 ; 95 \%$ confidence interval $[\mathrm{CI}]=0.5-4.9$ ) and Parkinsonism ${ }^{53}$ than extensive metabolizers. However, the OR did not reach significance. In addition, a randomized, blinded prospective study in Caucasian and African American cohorts did not find such an association. ${ }^{60}$ No pharmacokinetic studies have examined if TD is more common in poor metabolizers, or associated with higher serum antipsychotic levels in aripiprazole or thioridazine users. Small retrospective case-control studies have found a significant association between TD and CYP2D6 poor metabolizer alleles in both Japanese and Caucasian cohorts. ${ }^{17,62}$ However, only two small case-control studies, one cross-sectional and one longitudinal study, replicated this in both Caucasian and Chinese cohorts. ${ }^{63-66}$ Larger case-control studies did not find an association between TD and CYP2D6 polymorphisms in Korean, ${ }^{67}$ Japanese, ${ }^{47}$ Chinese, ${ }^{68}$ Caucasian, ${ }^{69-72}$ and Indian cohorts. ${ }^{73}$ These results were confirmed in a meta-analysis but no studies have examined the prospective use of CYP2D6 genotype test in clinical practice. Finally, a genome-wide association study on a longitudinal cohort of 710 subjects, of mixed ethnicity, found no correlation between TD and CYP2D6 polymorphisms. ${ }^{74}$

\section{CYPIA2}

CYP1A2 is the primary metabolizer for olanzapine and clozapine. CYP1A2 and CYP2D6 are the primary

Table 2 Ethnicity and cytochrome enzyme metabolic action

\begin{tabular}{|c|c|c|c|c|c|c|}
\hline \multirow[t]{2}{*}{ Ethnicity } & \multicolumn{2}{|l|}{ CYP2D6 } & \multicolumn{2}{|l|}{ CYP3A4 } & \multicolumn{2}{|c|}{ CYPIA2 } \\
\hline & PM & UM & PM & UM & PM & UM \\
\hline Caucasian & $8 \%^{33,34}$ & $1 \%-10 \%{ }^{163}$ & $2 \%-9.6 \% \%^{164}$ & $14 \% 162$ & NSD & NSD \\
\hline African & $3 \%-8 \%^{33,34}$ & $2 \%-29 \%{ }^{165}$ & $26 \%-67 \%^{164}$ & $67 \%^{162}$ & NSD & NSD \\
\hline Asian & $6 \%-10 \%^{33,34}$ & $0 \%-2 \%$ & $0 \%-22 \% 164$ & NSD & $5 \% 166$ & NSD \\
\hline Japanese & $0.39 \%^{35}$ & NSD & NSD & NSD & $14 \%{ }^{166}$ & NSD \\
\hline Korean & $0.22 \%^{36}$ & NSD & NSD & NSD & NSD & NSD \\
\hline Australian & NSD & NSD & NSD & NSD & $5 \%^{7}$ & NSD \\
\hline
\end{tabular}

Abbreviations: PM, poor metabolizers; UM, ultrafast metabolizers; NSD, no study done. 
metabolizers for thioridazine and perphenazine. ${ }^{59,75}$ A casecontrol study on 335 Indians found an association between CYP1A2*1C and $1545 \mathrm{~T}>\mathrm{C}$ polymorphisms and $\mathrm{TD}^{29} . \mathrm{Fu}$ et al found CYP1A2 -163 C/A T and C allele were associated with TD in a Chinese cohort of 182 patients. ${ }^{68}$ However, this was not replicated by a larger study of 291 Chinese subjects, which found no association between CYP1A2 polymorphisms and TD. ${ }^{76}$ Similarly, two case-control studies on a Turkish and a Caucasian cohort found no association between TD and CYP1A2 polymorphisms. ${ }^{77,78}$

\section{Other cytochrome P450 enzymes}

CYP3A4 is the primary metabolizer for quetiapine and together with CYP2D6 acts as the primary metabolizer for haloperidol and loxapine. ${ }^{79}$ CYP3A4 and CYP3A5 share sequence homology and substrate specificity ${ }^{80}$ and are capable of metabolizing a large number of substrates. A case-control study did not find an association between TD and CYP3A4*1B polymorphism in an Indian cohort. ${ }^{73}$ The presence of CYP3A5 was associated with TD in a subgroup of Caucasian males, although it did not reach significance for the entire cohort. ${ }^{61}$

\section{Dopamine receptor and its subtypes}

Dopamine receptor is upregulated in the post-synaptic membrane of the basal ganglia following chronic antipsychotic exposure in animal models. ${ }^{81}$ Subsequent hypersensitivity of the dopaminergic system is thought to be responsible for TD. ${ }^{82}$ Positron emission tomography found increased D2 receptor binding potential in subjects on chronic antipsychotic drugs compared to control subjects. ${ }^{83}$ While striatal $\mathrm{D} 2$ receptor density is not associated with TD, the severity of orofacial TD seems to depend on its relative density. ${ }^{84}$ Only one case-control study examined and found no association between the D1 dopamine receptor and TD. ${ }^{85}$ In contrast, D2 receptor TaqA A2, C957T and C939T polymorphisms were found to be associated with TD. Two case-control studies on Chinese cohorts and two meta-analyses on mixed ethnic cohorts found the $\mathrm{D} 2$ dopamine receptor TaqA A2 allele was associated with $\mathrm{TD}^{19,32,86,87}(\mathrm{OR}=1.80,95 \% \mathrm{CI}=1.03-1.65$; $P=0.03$ ). In contrast, one longitudinal cohort study in Caucasian subjects ${ }^{88}$ and four case-control studies in Indian, Chinese, Japanese, and Korean cohorts did not find such an association. ${ }^{85,89-91}$ There was no association between D2 receptor gene Ser311Cys or $-141 \mathrm{C}$ Ins/del polymorphisms with TD in three studies. ${ }^{89-91}$ One case-control study on a Caucasian and African American cohort $(n=232)$ found D2 receptor gene functional C957T polymorphism was associated with TD $(P=0.013)$ and higher abnormal involuntary movement scale score (AIMS) $(P=0.0087) .{ }^{92}$ The C957T haplotype was also associated with TD in the African American subcohort $(P=0.047) .{ }^{92}$ The same study found an adjacent C939T polymorphism was also associated with TD and a higher AIMS.

The association between the D3 receptor gene Ser9Gly polymorphism and TD seems to depend on ethnicity. A number of retrospective studies across Jewish, Russian and Asian cohorts have found an association between D3 receptor Ser9Gly Gly allele and Gly/Gly genotype with TD. ${ }^{21,61,89,93-95}$ However, two longitudinal cohort studies on Caucasian cohorts and one genome-wide association study found no such association. ${ }^{20,88,96}$ A meta-analysis found the Ser9Gly Gly/Gly genotype was highly associated with TD in a large Caucasian cohort, ${ }^{97}(\mathrm{OR}=1.52,95 \% \mathrm{CI}=1.08-1.68$, $P<0.0001)$ whereas a meta-analysis on the same polymorphism in an East Asian cohort $(n=1,291)$ did not replicate such finding $(\mathrm{OR}=0.94 ; 95 \% \mathrm{CI}=0.78-1.12 \text {. })^{98}$ The Ser9Gly polymorphism was also not associated with TD in Indian and African-Caribbean cohorts. ${ }^{85,99}$ Before routine testing for D3 receptor Ser9Gly polymorphisms can be recommended in schizophrenia patients, more evidence for its association would be required through large prospective pharmacogenomic studies. ${ }^{100}$

While D1, D2 and D3 dopamine receptor polymorphisms were not associated with TD in an Indian cohort of 335 patients, this study found that homozygosity for a 120 base pair duplication of the D4 dopamine receptor gene was associated with a reduced risk of $\mathrm{TD}^{85}(\mathrm{OR}=0.52,95 \% \mathrm{CI}=0.31-0.86$, $P=0.009$ ). Four tag polymorphisms (rs3758653, rs916457, rs762502, rs11246226) of the D4 receptor gene were associated with TD in males in a Caucasian cohort. ${ }^{101}$ However, another case-control study in Caucasian, Jewish, and Korean cohorts did not find an association between D4 receptor gene polymorphisms and TD. ${ }^{102-104}$

\section{Dopamine transporter gene}

The dopamine transporter (DAT1) mediates the reuptake of dopamine from the synapse and plays a role in dopaminergic transmission. Individuals with TD were found to have lower dopamine transporter density than those without TD. ${ }^{105}$ The two case-control studies (Jewish and Indian cohorts) did not find an association between DAT1 gene polymorphism and TD. ${ }^{85,103}$

\section{Brain-derived neurotrophic factor}

Brain-derived neurotrophic factor (BDNF) is capable of controlling D3 dopamine receptor (DRD3) expression in 
animal studies, promoting behavioral sensitization through overexpression of DRD3 in the striatum of hemiparkinsonian rats. ${ }^{106}$ It also has an influence on the survival, differentiation and function of dopaminergic neurons. ${ }^{107,108}$ As studies on the association between DRD3 and TD are conflicting, one case-control study on a Chinese cohort $(n=216)$ examined whether DRD3 ser9gly and brain-derived neurotrophic factor (BDNF) val66met genetic polymorphisms were associated with TD. ${ }^{109}$ They found patients with the BDNF Val66Met polymorphism had significantly higher AIMS than Val66Val or Met66Met homozygotes combined. However, this association was not replicated in a Caucasian cohort of 171 patients, nor was there an association between other BDNF polymorphisms and TD. ${ }^{110}$ Both glycogen synthase kinase (GSK)-3beta and BDNF are important in neuronal survival, and its regulation is hypothesized to play a role in susceptibility for TD. ${ }^{111}$ A study on a Korean cohort found GSK-3beta with C/C genotype and BDNF Val allele were associated with a decreased risk of TD (OR $=0.1,95 \%$ $\mathrm{CI}=0.02-0.48, P=0.001) .{ }^{112}$

\section{Glutathione S-transferase}

Glutathione S-transferase (GST) is a group of phase II detoxifying enzymes that conjugate glutathione to a range of compounds. A deletion of GST genes may lead to a build-up of toxic intermediates in the basal ganglia from increased dopamine turnover secondary to long-standing dopamine antagonist use. ${ }^{113}$ Neuronal toxicity through oxidative stress has been hypothesized as the pathophysiology of TD. One of the classes of glutathione, GSTM1, if deleted, is associated with schizophrenia. However, GSTM1 is not associated with TD nor correlated with higher AIMS. ${ }^{14,115}$ In contrast, one large Caucasian case-control study $(n=516)$ found an association between GSTM1 deletion and TD, particularly in the female subpopulation $(\mathrm{OR}=1.7,95 \% \mathrm{CI}=1.2-2.4$, $P=0.007) .{ }^{61}$ Similarly, studies examining the GSTP1 enzyme found conflicting results. One cross-sectional study found GSTP1 was associated with a reduced risk of TD and lower AIMS, ${ }^{116}$ while another case control study found no such association in a mixed ethnic cohort. ${ }^{117}$ To confirm the association between TD and GSTM1 or GSTP1 deletion, it needs to be replicated in future association studies.

\section{Glutathione peroxidase}

Glutathione peroxidase 1 (GPX1) is an antioxidant enzyme that reduces organic hydroperoxides and hydrogen peroxide. Pro197Leu is a functional polymorphism of GPX1, with the Leu allele being less responsive to stimulation of GPX1 enzyme activity, ${ }^{118}$ and potentially more at risk of oxidative stress. Both a cross-sectional study on a Russian cohort and case-control study on a Caucasian cohort did not find any association between Pro197Leu polymorphism and TD. ${ }^{116,119}$

\section{Manganese dependent superoxide dismutase- 2}

Manganese dependent superoxide dismutase-2 (MnSOD) is a mitochondrial enzyme that scavenges the largest amount of superoxide anions produced in the mitochondria. ${ }^{120}$ Neuronal toxicity through oxidative stress has been hypothesized as the pathophysiology of TD. Three case-control studies in Asian cohorts and one genome-wide association study found the Ala9Val polymorphism of MnSOD is not associated with TD. ${ }^{74,121-123}$ Whereas a cross-sectional study on a Russian cohort found the Val allele of Ala9Val polymorphism was associated with orofacial TD. ${ }^{116}$ This is in contrast with the finding from a meta-analysis, where Val allele of Ala9Val polymorphism was found to be protective against TD. The discrepancy in the results of these studies may be explained by the relative high Ala allele carriers in the Russian cohort (70\%), compared to the Asian cohort where 70\% were Val/ Val genotype, $30 \%$ were Val/Ala genotype and $0 \%$ had Ala/ Ala genotype. If Val allele truly offers a protective effect against TD, then this may explain the lack of association in the Asian cohort study. However, it would not explain the association between TD and Val allele of Ala9Val polymorphism in the Russian study.

\section{Catechol-O-methyltransferase and monoamine oxidase}

Catechol-O-methyltransferase (COMT) is a dopaminemetabolizing enzyme. Functional excess of dopamine in the postsynaptic cleft of the central nervous system has been hypothesized as a contributing factor to TD. Researchers have examined the possibility of COMT genetic polymorphism and its association with TD. The Val158Met is a functional polymorphism, where Met/Met genotype confers a 3- to 4-fold reduction in COMT enzyme activity, compared to Val/Val genotype. ${ }^{124}$ One large case-control study on Indian cohorts found the Val/Val genotype had a reduced risk of $\mathrm{TD}(\mathrm{OR}=0.24,95 \% \mathrm{CI}=0.11-0.55),{ }^{85}$ whereas a study on a Korean cohort found the Val/Val genotype had significantly higher incidence of TD than heterozygotes. ${ }^{125}$ However, three case-control studies on Chinese, Japanese and Turkish cohorts found no association between Val158Met polymorphism and TD. ${ }^{126-128}$ A meta-analysis of five studies found 
that Met carriers and Val-Met heterozygotes for Val158Met polymorphism of this enzyme, offered a protective effect against $\mathrm{TD}(\mathrm{OR}=0.66,95 \% \mathrm{CI}=0.49-0.88, P=0.005$ and $\mathrm{OR}=0.64,95 \% \mathrm{CI}=0.46-0.86, P=0.004$, respectively).$^{32} \mathrm{It}$ is difficult to draw a conclusion about the role of COMT in TD based on these studies and future prospective studies are needed for clarification.

Monoamine oxidase A (MAOA) and monoamine oxidase $\mathrm{B}$ (MAOB) both degrade dopamine and are thought to implicate susceptibility to TD. Functional polymorphism of MAOA such as 30 base pair (bp) repeat is thought to mediate transcriptional activity of this enzyme ${ }^{129}$ and intron 13 polymorphism of the MAOB gene is associated with MAOB enzyme activity in human platelets. ${ }^{130}$ Two case-control studies on Japanese and Caucasian cohorts did not find an association between MAOA 30 bp repeat polymorphism or MAOB polymorphism with TD. ${ }^{128,131}$

\section{Serotonin receptor gene $(5 \mathrm{HT})$}

Increased sensitivity of the striatal dopaminergic system after chronic dopamine antagonist use is proposed as the pathophysiological mechanism of TD. ${ }^{82}$ Serotonergic projections from the dorsal raphe lead to tonic inhibition of the nigrostriatal dopaminergic system ${ }^{132}$ and selective serotonin reuptake inhibitors have been associated with TD. ${ }^{4}$ Typical and atypical antipsychotic drugs have variable effects on the serotonergic system. Therefore investigators postulate that the serotonin receptor gene may play a role in the pathophysiology of TD. 5-HT2A receptor gene T102C polymorphism is a silent mutation, ${ }^{133}$ but interestingly has been reported to predict clozapine response in schizophrenia. ${ }^{134}$ A case-control study on a Jewish cohort ${ }^{135}$ and a longitudinal cohort study found the $\mathrm{T} 102 \mathrm{C}$ polymorphism $\mathrm{C} / \mathrm{C}$ genotype is associated with TD. ${ }^{88}$ However, other case-control studies and genome-wide association studies have not confirmed such an association because age is an additional risk factor in TD. ${ }^{74,126,136}$ The mean age of participants in the negative studies was between 33 and 40 years, compared with 52 years in the positive study. ${ }^{135}$ A meta-analysis combining the subjects from these studies by Lerer et al confirmed the T102C polymorphism conferred a small risk towards TD (OR $=1.64,95 \% \mathrm{CI}=1.17-2.32, P=0.002),{ }^{137}$ whereas the $\mathrm{T} / \mathrm{C}$ genotype or $\mathrm{T}$ allele is associated with non-TD group in Chinese cohorts. ${ }^{138,139}$ The $-1438 \mathrm{G} / \mathrm{A}$ polymorphism is associated with TD in two case-control studies, ${ }^{77,135}$ but this may be explained by its complete linkage equilibrium with T102C polymorphism. ${ }^{135}$ In studies on Indian, Russian, and African-Caribbean cohorts, no association between 5-HT2A receptor gene polymorphisms and TD has been found. ${ }^{34,95,99}$ Two case control studies did not find His452Tyr polymorphism conferring an increased risk towards TD. ${ }^{135,136}$

The role of the 5-HT2C receptor gene has been examined in several case-control studies. An 5-HT2C antagonist reduces cataplexy secondary to haloperidol ${ }^{140}$ and an injection of 5 -HT2C agonist in rats induces orofacial dyskinesia, ${ }^{141}$ therefore investigators postulate it may play a role in the pathophysiology of TD. The $-697 \mathrm{G} / \mathrm{C}$ polymorphism, located in the promoter region of the 5-HT2 $\mathrm{C}$ gene, has been associated with $\mathrm{TD}$ in a case study on a Chinese male cohort $(\mathrm{OR}=2.80,95 \%$ $\mathrm{CI}=1.08-7.27, P=0.03) .{ }^{142}$ In Jewish cohorts, the Cys23Ser polymorphism Ser allele is associated with higher orofacial dyskinesia AIMS $(P=0.0007)$ after controlling for age at antipsychotic initiation. ${ }^{143,144}$ In an African-Caribbean cohort, the combination of 23Ser allele and 9Ser carriership (DRD3 receptor gene polymorphism) or $-1438 \mathrm{~A} / \mathrm{G}$ (5-HT2A gene) polymorphisms in male patients was associated with a higher AIMS and TD, respectively. ${ }^{99}$ Whereas in a Russian cohort, the Ser allele of the Cys23Ser polymorphism was associated with a lower limb-trunk TD AIMS (OR $=0.7$, 95\% CI not published, $P=0.034) .{ }^{95}$ Interestingly, in the Indian cohort, there was no association between TD and 5-HT2C gene polymorphism. ${ }^{34}$ The 5HT6 receptor is upregulated in the extrapyramidal regions of the brain in animal studies, hence implicated in the pathophysiology of TD. ${ }^{145} 5$ HT6 receptor $267 \mathrm{~T} / \mathrm{C}$ polymorphism has not been found to be associated with TD in a case-control study. ${ }^{146}$ Similarly, no association between serotonin transporter gene polymorphism and TD has been found. ${ }^{126,139,147}$

\section{Nitric oxide synthase}

The nitric oxide synthase (NOS) enzyme produces nitric oxide, which is involved in oxidative stress. Animal studies implicated the likelihood of neural nitric oxide synthase (NOS1) and endothelial nitric oxide synthase (NOS3) in the pathophysiology of TD. ${ }^{148}$ Two studies examined the NOS1 gene and its C276T polymorphism and found no association with TD. ${ }^{149}$ A case-control study of 251 Chinese subjects did not find an association between AIMS and C276T genotypes. ${ }^{150}$ Liou et al found no association between single nucleotide polymorphisms such as 27-bp VNTR, Glu289Asp and -786T/C with TD in a Chinese cohort. However, they found the T-4b-Glu haplotype was associated with the non-TD group after correcting for duration of antipsychotic use and mean antipsychotic dose ( $O R=0.648$, $95 \% \mathrm{CI}=0.432-0.973, P=0.021) .{ }^{33} \mathrm{In}$ an Indian cohort, the 27-bp VNTR polymorphism was not associated with TD per 
se, but influences its severity, as 27-bp duplication correlates with a higher AIMS. ${ }^{151}$

\section{Quinone oxidoreductase}

Quinone oxidoreductase (NQO1) is a reductase enzyme located in the human substantia nigra. It is both an antioxidant and pro-oxidant. Its main function is to counteract the toxic dopamine semiquinone. Functional polymorphism of NQO1 with T allele is associated with reduced function, thus a potential mechanism for cellular damage and TD. Studies examining the $609 \mathrm{C}>\mathrm{T}$ polymorphism found the $\mathrm{T}$ allele is associated with a higher risk of TD and higher AIMS in a Korean cohort $(\mathrm{OR}=2.25,95 \% \mathrm{CI}=1.23-4.13, P=0.004),{ }^{152}$ but not in a Chinese cohort. ${ }^{33}$ This may be due to differences in allelic frequency within different ethnic groups and the exclusion of subjects on atypical antipsychotic drug in the negative study.

\section{Other gene polymorphisms}

Tyrosine hydroxylase $(\mathrm{TH})$ is the rate-limiting enzyme in dopamine synthesis. Val81Met polymorphism is a marker for dopamine susceptibility traits in the TH gene. A casecontrol study on a Korean cohort found no association between TD genotype and allele frequency for Val81Met polymorphism. ${ }^{153}$

The N-methyl-D-aspartate (NMDA) receptor has been implicated in TD pathogenesis through the glutamatergic neurotoxicity hypothesis. The $2 \mathrm{~B}$ subunit of NMDA receptor gene was investigated in a case-control study of 273 Chinese subjects. They found no association between genotype, allele frequency and TD occurrence, nor a significant difference between AIMS in the three genotypes. ${ }^{154}$

Regulators of G-protein signaling (RGS) are involved in signal termination of the G-protein coupled D2 dopamine receptor. D2 receptor hypersensitivity occurs following chronic dopamine antagonist use and is hypothesized as the pathophysiology of TD. A Korean case-control study examining the G-protein beta3 subunit gene found no association between the C825T polymorphism and TD. ${ }^{155}$ In contrast, a case-control study found the AGG haplotype is significantly associated with TD phenotype $(P=0.007) .{ }^{27}$ To date, the function of this haplotype is unknown and this result is yet to be replicated.

The cannabinoid receptor 1 (CNR1) activator inhibits movement and this effect is blocked by a cannabinoid receptor antagonist in animal models. ${ }^{156}$ Tiwari et al found rs806374 polymorphism $\mathrm{C} / \mathrm{C}$ genotype is associated with $\mathrm{TD}(P=0.036)$ and higher AIMS after correction for age and sex. ${ }^{30}$ When comparing haplotype across groups with or without TD, none was significant for TD.

Vesicular monoamine transporter 2 (VMAT2) is encoded by the SLC18A2 gene. It is responsible for the release of neurotransmitters implicated in TD, such as dopamine, serotonin and gamma-aminobutyric acid. VMAT2 is also the target for tetrabenazine, a drug used in TD. Zai et al found a number of single nucleotide polymorphisms associated with TD occurrence and higher AIMS. This rs363224 marker interacts with functional D2 receptor C957T polymorphism. ${ }^{28}$

The alpha-1A adrenergic receptor (ARRB2) is an important target for atypical antipsychotic drugs and linked to the potential extrapyramidal side effect of these drugs. ${ }^{157,158}$ A case-control study on a Chinese cohort found polymorphism rs1045280 (Ser280ser) in the ARRB2 gene is associated with TD compared to the non-TD group. ${ }^{31}$ In contrast, Saiz et al examined the effect of three single nucleotide polymorphisms, $-563 \mathrm{C} / \mathrm{T},-4155 \mathrm{C} / \mathrm{G}$ and $-4884 \mathrm{~A} / \mathrm{G}$, and their effect on TD on 427 Caucasian subjects who were on typical and atypical antipsychotics. Apart from the $-4155 \mathrm{C} / \mathrm{C}$ genotype whose association with severe TD trended towards significance, they found the other genotypes were not associated with TD after controlling for age and multiple factors. ${ }^{26}$ Future replicable studies for VMAT2, CNR1 and ARRB2 receptor gene polymorphism and TD are needed.

Akt1 is a protein kinase that provides downstream signal transduction for the D2 receptor. ${ }^{159}$ Akt1 has an important influence on regulation of neuronal plasticity through receptor phosphorylation and upregulation. ${ }^{160}$ Therefore Aktl may play a role in dopaminergic association conditions such as TD. However a case-control study on a mixed ethnic population found no significant association between the Akt1 gene haplotypes and TD. The same study found a significant interaction between theAkt1 rs3730358 haplotype and DRD2 rs6275 haplotype. ${ }^{161}$ It is not known how these haplotypes may cause TD and interaction analysis with larger sample studies is needed.

\section{Conclusion}

There is a lack of prospective pharmacogenomic studies investigating the clinical utility and cost-effectiveness of genetic polymorphisms in predicting TD in psychiatric patients. Further studies are needed before there is enough evidence to recommend routine genotyping with predictive information for counselling and/or prevention. To date, meta-analysis of retrospective studies suggests that the D3 dopamine receptor Ser9Gly polymorphism and D2 dopamine receptor TaqA polymorphism are potential targets for prospective pharmacogenomic studies. Conflicting results for CYP2D6, CYP1A2, 
COMT and 5-HT2A T102C polymorphisms may also benefit from prospective well-designed studies, gene polymorphism interaction studies and studies into the epigenetics of receptor polymorphisms. More association studies are required for D4 receptor, BDNF, GSK3-beta, GSTM, GSTP, MnSOD, 5-HT2C, NOS3, NQO1, RGS9, CRN1, VMAT2 and ARRB2 genetic polymorphism. To date, studies have shown no association between CYP3A4 and CYP3A5, DAT, GPX1, MAOA, MAOB, 5-HTT, NOS1, TH, and NMDA 2B genetic polymorphisms with TD.

\section{Disclosure}

The authors report no conflict of interest in this work.

\section{References}

1. Evans WE, Relling MV. Pharmacogenomics: translating functional genomics into rational therapeutics. Science. 1999;286(5439):487-491.

2. Newman WG, Payne K, Tricker K, et al; TARGET study recruitment team. A pragmatic randomized controlled trial of thiopurine methyltransferase genotyping prior to azathioprine treatment: the TARGET study. Pharmacogenomics. 2011;12(6):815-826.

3. Gardos G, Casey DE, Cole JO, et al. Ten-year outcome of tardive dyskinesia. Am J Psychiatry. 1994;151(6):836-841.

4. Leo RJ. Movement disorders associated with the serotonin selective reuptake inhibitors. J Clin Psychiatry. 1996;57(10):449-454.

5. Jankovic J. Tardive syndromes and other drug-induced movement disorders. Clin Neuropharmacol. 1995;18(3):197-214.

6. Chiu H, Shum P, Lau J, Lam L, Lee S. Prevalence of tardive dyskinesia, tardive dystonia, and respiratory dyskinesia among Chinese psychiatric patients in Hong Kong. Am J Psychiatry. 1992;149(8):1081-1085.

7. Sramek J, Roy S, Ahrens T, Pinanong P, Cutler NR, Pi E. Prevalence of tardive dyskinesia among three ethnic groups of chronic psychiatric patients. Hosp Community Psychiatry. 1991;42(6):590-592.

8. van Harten PN, Matroos GE, Hoek HW, Kahn RS. The prevalence of tardive dystonia, tardive dyskinesia, parkinsonism and akathisia The Curacao Extrapyramidal Syndromes Study: I. Schizophr Res. 1996; 19(2-3):195-203.

9. Baldessarini RJ. Clinical and epidemiologic aspects of tardive dyskinesia. J Clin Psychiatry. 1985;46(4 Pt 2):8-13.

10. Xiang YT, Wang CY, Si TM, et al. Tardive dyskinesia in the treatment of schizophrenia: the findings of the Research on Asian Psychotropic Prescription Pattern (REAP) survey (2001 - 2009). Int J Clin Pharmacol Ther. 2011;49(6):382-387.

11. Swartz JR, Burgoyne K, Smith M, Gadasally R, Ananth J, Ananth K. Tardive dyskinesia and ethnicity: review of the literature. Ann Clin Psychiatry. 1997;9(1):53-59.

12. Wonodi I, Adami HM, Cassady SL, Sherr JD, Avila MT, Thaker GK. Ethnicity and the course of tardive dyskinesia in outpatients presenting to the motor disorders clinic at the Maryland psychiatric research center. J Clin Psychopharmacol. 2004;24(6):592-598.

13. Eastham JH, Lacro JP, Jeste DV. Ethnicity and movement disorders. Mt Sinai J Med. 1996;63(5-6):314-319.

14. Yassa R, Ananth J. Familial tardive dyskinesia. Am J Psychiatry. 1981;138(12):1618-1619.

15. Weinhold P, Wegner JT, Kane JM. Familial occurrence of tardive dyskinesia. J Clin Psychiatry. 1981;42(4):165-166.

16. Müller DJ, Schulze TG, Knapp M, et al. Familial occurrence of tardive dyskinesia. Acta Psychiatr Scand. 2001;104(5):375-379.

17. Kapitany T, Meszaros K, Lenzinger E, et al. Genetic polymorphisms for drug metabolism (CYP2D6) and tardive dyskinesia in schizophrenia. Schizophr Res. 1998;32(2):101-106.
18. Fleeman N, Dundar Y, Dickson R, et al. Cytochrome P450 testing for prescribing antipsychotics in adults with schizophrenia: systematic review and meta-analyses. Pharmacogenomics J. 2011;11(1):1-14.

19. Chen CH, Wei FC, Koong FJ, Hsiao KJ. Association of TaqI A polymorphism of dopamine D2 receptor gene and tardive dyskinesia in schizophrenia. Biol Psychiatry. 1997;41(7):827-829.

20. Steen VM, Lovlie R, MacEwan T, McCreadie RG. Dopamine D3-receptor gene variant and susceptibility to tardive dyskinesia in schizophrenic patients. Mol Psychiatry. 1997;2(2):139-145.

21. Segman R, Neeman T, Heresco-Levy U, et al. Genotypic association between the dopamine D3 receptor and tardive dyskinesia in chronic schizophrenia. Mol Psychiatry. 1999;4(3):247-253.

22. Galili R, Mosberg, Gil-Ad I, Weizman A, Melamed E, Offen D. Haloperidol-induced neurotoxicity - possible implications for tardive dyskinesia. J Neural Transm. 2000;107(4):479-490.

23. Post A, Holsboer F, Behl C. Induction of NF-kappaB activity during haloperidol-induced oxidative toxicity in clonal hippocampal cells: suppression of NF-kappaB and neuroprotection by antioxidants. J Neurosci. 1998;18(20):8236-8246.

24. Behl C, Rupprecht R, Skutella T, Holsboer F. Haloperidol-induced cell death - mechanism and protection with vitamin $\mathrm{E}$ in vitro. Neuroreport. 1995;7(1):360-364.

25. Elkashef AM, Wyatt RJ. Tardive dyskinesia: possible involvement of free radicals and treatment with vitamin E. Schizophr Bull. 1999;25(4): 731-740.

26. Saiz PA, Susce MT, Clark DA, et al. An investigation of the alpha1Aadrenergic receptor gene and antipsychotic-induced side-effects. Hum Psychopharmacol. 2008;23(2):107-114.

27. Liou YJ, Chen ML, Wang YC, et al. Analysis of genetic variations in the RGS9 gene and antipsychotic-induced tardive dyskinesia in schizophrenia. Am J Med Genet B Neuropsychiatr Genet. 2009;150B(2):239-242.

28. Zai CC, Tiwari AK, Mazzoco M, et al. Association study of the vesicular monoamine transporter gene SLC18A2 with tardive dyskinesia. $J$ Psychiatr Res. 2013;47(11):1760-1765.

29. Tiwari AK, Deshpande SN, Lerer B, Nimgaonkar VL, Thelma BK. Genetic susceptibility to Tardive Dyskinesia in chronic schizophrenia subjects: V. Association of CYP1A2 $1545 \mathrm{C}>\mathrm{T}$ polymorphism. Pharmacogenomics J. 2007;7(5):305-311.

30. Tiwari AK, Zai CC, Likhodi O, et al. Association study of cannabinoid receptor 1 (CNR1) gene in tardive dyskinesia. Pharmacogenomics $J$. 2012;12(3):260-266.

31. Liou YJ, Wang YC, Chen JY, et al. The coding-synonymous polymorphism rs 1045280 (Ser280Ser) in beta-arrestin 2 (ARRB2) gene is associated with tardive dyskinesia in Chinese patients with schizophrenia. Eur J Neurol. 2008;15(12):1406-1408.

32. Bakker PR, van Harten PN, van Os J. Antipsychotic-induced tardive dyskinesia and polymorphic variations in COMT, DRD2, CYP1A2 and MnSOD genes: a meta-analysis of pharmacogenetic interactions. Mol Psychiatry. 2008;13(5):544-556.

33. Liou YJ, Lai IC, Lin MW, et al. Haplotype analysis of endothelial nitric oxide synthase (NOS3) genetic variants and tardive dyskinesia in patients with schizophrenia. Pharmacogenet Genomics. 2006;16(3): 151-157.

34. Deshpande SN, Varma PG, Semwal P, et al. II. Serotonin receptor gene polymorphisms and their association with tardive dyskinesia among schizophrenia patients from North India. Psychiatr Genet. 2005;15(3): 157-158.

35. Cascorbi I. Pharmacogenetics of cytochrome p4502D6: genetic background and clinical implication. Eur J Clin Invest. 2003;33 Suppl 2: $17-22$.

36. Bertilsson L, Dahl ML, Dalen P, Al-Shurbaji A. Molecular genetics of CYP2D6: clinical relevance with focus on psychotropic drugs. $\mathrm{Br} J$ Clin Pharmacol. 2002;53(2):111-122.

37. Chida M, Yokoi T, Nemoto N, Inaba M, Kinoshita M, Kamataki T. A new variant CYP2D6 allele (CYP2D6*21) with a single base insertion in exon 5 in a Japanese population associated with a poor metabolizer phenotype. Pharmacogenetics. 1999;9(3):287-293. 
38. Lee SY, Sohn KM, Ryu JY, Yoon YR, Shin JG, Kim JW. Sequencebased CYP2D6 genotyping in the Korean population. Ther Drug Monit. 2006;28(3):382-387.

39. Llerena A, Dahl ML, Ekqvist B, Bertilsson L. Haloperidol disposition is dependent on the debrisoquine hydroxylation phenotype: increased plasma levels of the reduced metabolite in poor metabolizers. Ther Drug Monit. 1992;14(3):261-264.

40. Pan L, Vander Stichele R, Rosseel MT, Berlo JA, De Schepper N, Belpaire FM. Effects of smoking, CYP2D6 genotype, and concomitant drug intake on the steady state plasma concentrations of haloperidol and reduced haloperidol in schizophrenic inpatients. Ther Drug Monit. 1999;21(5):489-497.

41. Yasui-Furukori N, Kondo T, Suzuki A, et al. Effect of the CYP2D6 genotype on prolactin concentration in schizophrenic patients treated with haloperidol. Schizophr Res. 2001;52(1-2):139-142.

42. Brockmoller J, Kirchheiner J, Schmider J, et al. The impact of the CYP2D6 polymorphism on haloperidol pharmacokinetics and on the outcome of haloperidol treatment. Clin Pharmacol Ther. 2002;72(4): 438-452.

43. Desai M, Tanus-Santos JE, Li L, et al. Pharmacokinetics and QT interval pharmacodynamics of oral haloperidol in poor and extensive metabolizers of CYP2D6. Pharmacogenomics J. 2003;3(2):105-113.

44. Llerena A, Berecz R, Dorado P, de la Rubia A. QTc interval, CYP2D6 and CYP2C9 genotypes and risperidone plasma concentrations. J Psychopharmacol. 2004;18(2):189-193.

45. A LL, de la Rubia A, Berecz R, Dorado P. Relationship between haloperidol plasma concentration, debrisoquine metabolic ratio, CYP2D6 and CYP2C9 genotypes in psychiatric patients. Pharmacopsychiatry. 2004;37(2):69-73.

46. Panagiotidis G, Arthur HW, Lindh JD, Dahl ML, Sjöqvist F. Depot haloperidol treatment in outpatients with schizophrenia on monotherapy: impact of CYP2D6 polymorphism on pharmacokinetics and treatment outcome. Ther Drug Monit. 2007;29(4):417-422.

47. Inada T, Senoo H, Iijima Y, Yamauchi T, Yagi G. Cytochrome P450 II D6 gene polymorphisms and the neuroleptic-induced extrapyramidal symptoms in Japanese schizophrenic patients. Psychiatr Genet. 2003;13(3):163-168.

48. Hendset M, Hermann M, Lunde H, Refsum H, Molden E. Impact of the CYP2D6 genotype on steady-state serum concentrations of aripiprazole and dehydroaripiprazole. Eur J Clin Pharmacol. 2007;63(12):1147-1151.

49. Swen JJ, Nijenhuis M, de Boer A, et al. Pharmacogenetics: from bench to byte - an update of guidelines. Clin Pharmacol Ther. 2011;89(5): $662-673$.

50. Kohnke MD, Griese EU, Stosser D, Gaertner I, Barth G. Cytochrome P450 2D6 deficiency and its clinical relevance in a patient treated with risperidone. Pharmacopsychiatry. 2002;35(3):116-118.

51. Jerling M, Dahl ML, Aberg-Wistedt A, et al. The CYP2D6 genotype predicts the oral clearance of the neuroleptic agents perphenazine and zuclopenthixol. Clin Pharmacol Ther. 1996;59(4):423-428.

52. Linnet $\mathrm{K}$, Wiborg O. Influence of Cyp2D6 genetic polymorphism on ratios of steady-state serum concentration to dose of the neuroleptic zuclopenthixol. Ther Drug Monit. 1996;18(6):629-634.

53. Jaanson P, Marandi T, Kiivet RA, et al. Maintenance therapy with zuclopenthixol decanoate: associations between plasma concentrations, neurological side effects and CYP2D6 genotype. Psychopharmacology (Berl). 2002;162(1):67-73.

54. Dahl ML, Ekqvist B, Widén J, Bertilsson L. Disposition of the neuroleptic zuclopenthixol cosegregates with the polymorphic hydroxylation of debrisoquine in humans. Acta Psychiatr Scand. 1991;84(1):99-102.

55. Dahl-Puustinen ML, Lidén A, Alm C, Nordin C, Bertilsson L. Disposition of perphenazine is related to polymorphic debrisoquin hydroxylation in human beings. Clinical Pharmacology and Therapeutics. 1989;46(1):78-81.

56. Ozdemir V, Bertilsson L, Miura J, et al. CYP2D6 genotype in relation to perphenazine concentration and pituitary pharmacodynamic tissue sensitivity in Asians: CYP2D6-serotonin-dopamine crosstalk revisited. Pharmacogenet Genomics. 2007;17(5):339-347.
57. Eap CB, Guentert TW, Schãublin-Loidl M, et al. Plasma levels of the enantiomers of thioridazine, thioridazine 2-sulfoxide, thioridazine 2-sulfone, and thioridazine 5-sulfoxide in poor and extensive metabolizers of dextromethorphan and mephenytoin. Clin Pharmacol Ther. 1996;59(3):322-331.

58. Berecz R, de la Rubia A, Dorado P, et al. Thioridazine steady-state plasma concentrations are influenced by tobacco smoking and CYP2D6, but not by the CYP2C9 genotype. Eur J Clin Pharmacol. 2003;59(1): 45-50.

59. Wójcikowski J, Maurel P, Daniel WA. Characterization of human cytochrome $\mathrm{p} 450$ enzymes involved in the metabolism of the piperidinetype phenothiazine neuroleptic thioridazine. Drug Metab Dispos. 2006;34(3):471-476.

60. Grossman I, Sullivan PF, Walley N, et al. Genetic determinants of variable metabolism have little impact on the clinical use of leading antipsychotics in the CATIE study. Genet Med. 2008;10(10):720-729.

61. de Leon J, Susce MT, Pan RM, Koch WH, Wedlund PJ. Polymorphic variations in GSTM1, GSTT1, PgP, CYP2D6, CYP3A5, and dopamine D2 and D3 receptors and their association with tardive dyskinesia in severe mental illness. J Clin Psychopharmacol. 2005;25(5):448-456.

62. Ohmori O, Suzuki T, Kojima H, et al. Tardive dyskinesia and debrisoquine 4-hydroxylase (CYP2D6) genotype in Japanese schizophrenics. Schizophr Res. 1998;32(2):107-113.

63. Crescenti A, Mas S, Gasso P, Parellada E, Bernardo M, Lafuente A. Cyp2d6*3, *4, *5 and *6 polymorphisms and antipsychotic-induced extrapyramidal side-effects in patients receiving antipsychotic therapy. Clin Exp Pharmacol Physiol. 2008;35(7):807-811.

64. Ellingrod VL, Schultz SK, Arndt S. Abnormal movements and tardive dyskinesia in smokers and nonsmokers with schizophrenia genotyped for cytochrome P450 2D6. Pharmacotherapy. 2002;22(11):1416-1419.

65. Koola MM, Tsapakis EM, Wright P, et al. Association of tardive dyskinesia with variation in CYP2D6: Is there a role for active metabolites? J Psychopharmacol. March 4, 2014;28(7):665-670.

66. Liou YJ, Wang YC, Bai YM, et al. Cytochrome P-450 2D6*10 C188T polymorphism is associated with antipsychotic-induced persistent tardive dyskinesia in Chinese schizophrenic patients. Neuropsychobiology. 2004;49(4):167-173.

67. Nikoloff D, Shim JC, Fairchild M, et al. Association between CYP2D6 genotype and tardive dyskinesia in Korean schizophrenics. Pharmacogenomics J. 2002;2(6):400-407.

68. Fu Y, Fan CH, Deng HH, et al. Association of CYP2D6 and CYP1A2 gene polymorphism with tardive dyskinesia in Chinese schizophrenic patients. Acta Pharmacol Sin. 2006;27(3):328-332.

69. Andreassen OA, MacEwan T, Gulbrandsen AK, McCreadie RG, Steen VM. Non-functional CYP2D6 alleles and risk for neuroleptic-induced movement disorders in schizophrenic patients. Psychopharmacology (Berl). 1997;131(2):174-179.

70. Scordo MG, Spina E, Romeo P, et al. CYP2D6 genotype and antipsychotic-induced extrapyramidal side effects in schizophrenic patients. Eur J Clin Pharmacol. 2000;56(9-10):679-683.

71. Lohmann PL, Bagli M, Krauss H, et al. CYP2D6 polymorphism and tardive dyskinesia in schizophrenic patients. Pharmacopsychiatry. 2003;36(2):73-78

72. de Leon J, Susce MT, Pan RM, Fairchild M, Koch WH, Wedlund PJ. The CYP2D6 poor metabolizer phenotype may be associated with risperidone adverse drug reactions and discontinuation. J Clin Psychiatry. 2005;66(1):15-27.

73. Tiwari AK, Deshpande SN, Rao AR, et al. Genetic susceptibility to tardive dyskinesia in chronic schizophrenia subjects: III. Lack of association of CYP3A4 and CYP2D6 gene polymorphisms. Schizophr Res. $2005 ; 75(1): 21-26$

74. Tsai HT, Caroff SN, Miller DD, et al. A candidate gene study of Tardive dyskinesia in the CATIE schizophrenia trial. Am J Med Genet B Neuropsychiatr Genet. 2010;153B(1):336-340.

75. Murray M. Role of CYP pharmacogenetics and drug-drug interactions in the efficacy and safety of atypical and other antipsychotic agents. J Pharm Pharmacol. 2006;58(7):871-885. 
76. Chong SA, Tan EC, Tan CH, Mythily. Smoking and tardive dyskinesia: lack of involvement of the CYP1A2 gene. J Psychiatry Neurosci. 2003;28(3):185-189.

77. Boke O, Gunes S, Kara N, et al. Association of serotonin 2A receptor and lack of association of CYP1A2 gene polymorphism with tardive dyskinesia in a Turkish population. DNA Cell Biol. 2007;26(8):527-531.

78. Schulze TG, Schumacher J, Müller DJ, et al. Lack of association between a functional polymorphism of the cytochrome P450 1A2 (CYP1A2) gene and tardive dyskinesia in schizophrenia. Am J Med Genet. 2001;105(6):498-501.

79. Ravyn D, Ravyn V, Lowney R, Nasrallah HA. CYP450 pharmacogenetic treatment strategies for antipsychotics: a review of the evidence. Schizophr Res. 2013;149(1-3):1-14.

80. McGraw J, Waller D. Cytochrome P450 variations in different ethnic populations. Expert Opin Drug Metab Toxicol. 2012;8(3):371-382.

81. Meshul CK, Casey DE. Regional, reversible ultrastructural changes in rat brain with chronic neuroleptic treatment. Brain Res. 1989;489(2): 338-346.

82. Casey DE, Gerlach J, Bjorndal N. Levodopa and receptor sensitivity modification in tardive dyskinesia. Psychopharmacology (Berl). 1982;78(1):89-92.

83. Silvestri S, Seeman MV, Negrete JC, et al. Increased dopamine D2 receptor binding after long-term treatment with antipsychotics in humans: a clinical PET study. Psychopharmacology (Berl). 2000;152(2):174-180.

84. Blin J, Baron JC, Cambon H, et al. Striatal dopamine D2 receptors in tardive dyskinesia: PET study. J Neurol Neurosurg Psychiatry. 1989;52(11):1248-1252.

85. Srivastava V, Varma PG, Prasad S, et al. Genetic susceptibility to tardive dyskinesia among schizophrenia subjects: IV. Role of dopaminergic pathway gene polymorphisms. Pharmacogenet Genomics. 2006;16(2): 111-117.

86. Liou YJ, Lai IC, Liao DL, et al. The human dopamine receptor D2 (DRD2) gene is associated with tardive dyskinesia in patients with schizophrenia. Schizophr Res. 2006;86(1-3):323-325.

87. Zai CC, De Luca V, Hwang RW, et al. Meta-analysis of two dopamine D2 receptor gene polymorphisms with tardive dyskinesia in schizophrenia patients. Mol Psychiatry. 2007;12(9):794-795.

88. Lattuada E, Cavallaro R, Serretti A, Lorenzi C, Smeraldi E. Tardive dyskinesia and DRD2, DRD3, DRD4, 5-HT2A variants in schizophrenia: an association study with repeated assessment. Int $J$ Neuropsychopharmacol. 2004;7(4):489-493.

89. Chong SA, Tan EC, Tan CH, Mythily, Chan YH. Polymorphisms of dopamine receptors and tardive dyskinesia among Chinese patients with schizophrenia. Am JMed Genet B Neuropsychiatr Genet. 2003;116B(1): 51-54.

90. Hori H, Ohmori O, Shinkai T, Kojima H, Nakamura J. Association between three functional polymorphisms of dopamine D2 receptor gene and tardive dyskinesia in schizophrenia. Am J Med Genet. 2001;105(8):774-778.

91. Park YM, Kang SG, Choi JE, et al. No Evidence for an Association between Dopamine D2 Receptor Polymorphisms and Tardive Dyskinesia in Korean Schizophrenia Patients. Psychiatry Investig. 2011;8(1):49-54.

92. Zai CC, Hwang RW, De Luca V, et al. Association study of tardive dyskinesia and twelve DRD2 polymorphisms in schizophrenia patients. Int J Neuropsychopharmacol. 2007;10(5):639-651.

93. Woo SI, Kim JW, Rha E, et al. Association of the Ser9Gly polymorphism in the dopamine D3 receptor gene with tardive dyskinesia in Korean schizophrenics. Psychiatry Clin Neurosci. 2002;56(4):469-474.

94. Liao DL, Yeh YC, Chen HM, Chen H, Hong CJ, Tsai SJ. Association between the Ser9Gly polymorphism of the dopamine D3 receptor gene and tardive dyskinesia in Chinese schizophrenic patients. Neuropsychobiology. 2001;44(2):95-98.

95. Al Hadithy AF, Ivanova SA, Pechlivanoglou P, et al. Tardive dyskinesia and DRD3, HTR2A and HTR2C gene polymorphisms in Russian psychiatric inpatients from Siberia. Prog Neuropsychopharmacol Biol Psychiatry. 2009;33(3):475-481.
96. Tsai HT, North KE, West SL, Poole C. The DRD3 rs6280 polymorphism and prevalence of tardive dyskinesia: a meta-analysis. Am J Med Genet B Neuropsychiatr Genet. 2010;153B(1):57-66.

97. Lerer B, Segman RH, Fangerau H, et al. Pharmacogenetics of tardive dyskinesia: combined analysis of 780 patients supports association with dopamine D3 receptor gene Ser9Gly polymorphism. Neuropsychopharmacology. 2002;27(1):105-119.

98. Utsunomiya K, Shinkai T, Sakata S, et al. Genetic association between the dopamine D3 receptor gene polymorphism (Ser9Gly) and tardive dyskinesia in patients with schizophrenia: a reevaluation in East Asian populations. Neurosci Lett. 2012;507(1):52-56.

99. Wilffert B, Al Hadithy AF, Sing VJ, et al. The role of dopamine D3, 5-HT2A and 5-HT2C receptor variants as pharmacogenetic determinants in tardive dyskinesia in African-Caribbean patients under chronic antipsychotic treatment: Curacao extrapyramidal syndromes study IX. J Psychopharmacol. 2009;23(6):652-659.

100. Shamy MC, Zai C, Basile VS, Kennedy JL, Müller DJ, Masellis M. Ethical and Policy Considerations in the Application of Pharmacogenomic Testing for Tardive Dyskinesia: Case Study of the Dopamine D3 Receptor. Curr Pharmacogenomics Person Med. 2011;9(2): 94-101.

101. Zai CC, Tiwari AK, Basile V, et al. Association study of tardive dyskinesia and five DRD4 polymorphisms in schizophrenia patients. Pharmacogenomics J. 2009;9(3):168-174.

102. Rietschel M, Krauss H, Müller DJ, et al. Dopamine D3 receptor variant and tardive dyskinesia. Eur Arch Psychiatry Clin Neurosci. 2000;250(1):31-35.

103. Segman RH, Goltser T, Heresco-Levy U, et al. Association of dopaminergic and serotonergic genes with tardive dyskinesia in patients with chronic schizophrenia. Pharmacogenomics J. 2003;3(5):277-283.

104. Lee HJ, Kang SG, Choi JE, et al. No association between dopamine D4 receptor gene $-521 \mathrm{C} / \mathrm{T}$ polymorphism and tardive dyskinesia in schizophrenia. Neuropsychobiology. 2007;55(1):47-51.

105. Yoder KK, Hutchins GD, Morris ED, Brashear A, Wang C, Shekhar A. Dopamine transporter density in schizophrenic subjects with and without tardive dyskinesia. Schizophr Res. 2004;71(2-3):371-375.

106. Guillin O, Diaz J, Carroll P, Griffon N, Schwartz JC, Sokoloff P. BDNF controls dopamine D3 receptor expression and triggers behavioural sensitization. Nature. 2001;411(6833):86-89.

107. Knüsel B, Winslow JW, Rosenthal A, et al. Promotion of central cholinergic and dopaminergic neuron differentiation by brain-derived neurotrophic factor but not neurotrophin 3. Proc Natl Acad Sci USA. 1991;88(3):961-965.

108. Beck KD, Knüsel B, Hefti F. The nature of the trophic action of brainderived neurotrophic factor, des(1-3)-insulin-like growth factor-1, and basic fibroblast growth factor on mesencephalic dopaminergic neurons developing in culture. Neuroscience. 1993;52(4):855-866.

109. Liou YJ, Liao DL, Chen JY, et al. Association analysis of the dopamine D3 receptor gene ser9gly and brain-derived neurotrophic factor gene val66met polymorphisms with antipsychotic-induced persistent tardive dyskinesia and clinical expression in Chinese schizophrenic patients. Neuromolecular Med. 2004;5(3):243-251.

110. Zai CC, Tiwari AK, De Luca V, et al. Genetic study of BDNF, DRD3, and their interaction in tardive dyskinesia. Eur Neuropsychopharmacol. 2009;19(5):317-328.

111. Jope RS, Roh MS. Glycogen synthase kinase-3 (GSK3) in psychiatric diseases and therapeutic interventions. Curr Drug Targets. 2006;7(11): 1421-1434.

112. Park SW, Lee JG, Kong BG, et al. Genetic association of BDNF val66met and GSK-3beta-50T/C polymorphisms with tardive dyskinesia. Psychiatry Clin Neurosci. 2009;63(4):433-439.

113. Lohr JB, Kuczenski R, Niculescu AB. Oxidative mechanisms and tardive dyskinesia. CNS Drugs. 2003;17(1):47-62.

114. Harada S, Tachikawa H, Kawanishi Y. Glutathione S-transferase M1 gene deletion may be associated with susceptibility to certain forms of schizophrenia. Biochem Biophys Res Commun. 2001;281(2): 267-271. 
115. Pae CU, Yu HS, Kim JJ, et al. Glutathione S-transferase M1 polymorphism may contribute to schizophrenia in the Korean population. Psychiatr Genet. 2004;14(3):147-150.

116. Al Hadithy AF, Ivanova SA, Pechlivanoglou P, et al. Missense polymorphisms in three oxidative-stress enzymes (GSTP1, SOD2, and GPX1) and dyskinesias in Russian psychiatric inpatients from Siberia. Hum Psychopharmacol. 2010;25(1):84-91.

117. Shinkai T, De Luca V, Hwang R, et al. Association study between a functional glutathione S-transferase (GSTP1) gene polymorphism (Ile105Val) and tardive dyskinesia. Neurosci Lett. 2005;388(2):116-120.

118. Hu YJ, Diamond AM. Role of glutathione peroxidase 1 in breast cancer: loss of heterozygosity and allelic differences in the response to selenium. Cancer Res. 2003;63(12):3347-3351.

119. Shinkai T, Müller DJ, De Luca V, et al. Genetic association analysis of the glutathione peroxidase (GPX1) gene polymorphism (Pro197Leu) with tardive dyskinesia. Psychiatry Res. 2006;141(2): 123-128.

120. Hori H, Ohmori O, Shinkai T, et al. Manganese superoxide dismutase gene polymorphism and schizophrenia: relation to tardive dyskinesia. Neuropsychopharmacology. 2000;23(2):170-177.

121. Zhang Z, Zhang X, Hou G, Sha W, Reynolds GP. The increased activity of plasma manganese superoxide dismutase in tardive dyskinesia is unrelated to the Ala-9Val polymorphism. J Psychiatr Res. 2002;36(5): 317-324.

122. Pae CU, Kim TS, Patkar AA, et al. Manganese superoxide dismutase (MnSOD: Ala-9Val) gene polymorphism may not be associated with schizophrenia and tardive dyskinesia. Psychiatry Res. 2007;153(1): 77-81.

123. Liu H, Wang C, Chen PH, et al. Association of the manganese superoxide dismutase gene Ala-9Val polymorphism with clinical phenotypes and tardive dyskinesia in schizophrenic patients. Prog Neuropsychopharmacol Biol Psychiatry. 2010;34(4):692-696.

124. Lachman HM, Papolos DF, Saito T, Yu YM, Szumlanski CL, Weinshilboum RM. Human catechol-O-methyltransferase pharmacogenetics: description of a functional polymorphism and its potential application to neuropsychiatric disorders. Pharmacogenetics. 1996;6(3):243-250

125. Han D, Lee J, Lee Y, Kee B, Min KJ, Na C. The association between tardive dyskinesia induced by haloperidol and polymorphisms in the serotonin transporter gene and catecholamine-o-methyltransferase gene in Korean schizophrenic patients. Clinical Psychopharmacology and Neuroscience. 2005;3(1):16-21.

126. Herken H, Erdal ME, Boke O, Savas HA. Tardive dyskinesia is not associated with the polymorphisms of 5-HT2A receptor gene, serotonin transporter gene and catechol-o-methyltransferase gene. Eur Psychiatry. 2003;18(2):77-81.

127. Lai IC, Wang YC, Lin CC, et al. Negative association between catechol-O-methyltransferase (COMT) gene Val158Met polymorphism and persistent tardive dyskinesia in schizophrenia. J Neural Transm. 2005;112(8):1107-1113.

128. Matsumoto C, Shinkai T, Hori H, Ohmori O, Nakamura J. Polymorphisms of dopamine degradation enzyme (COMT and MAO) genes and tardive dyskinesia in patients with schizophrenia. Psychiatry Res. 2004;127(1-2):1-7.

129. Sabol SZ, Hu S, Hamer D. A functional polymorphism in the monoamine oxidase A gene promoter. Hum Genet. 1998;103(3): 273-279.

130. Garpenstrand H, Ekblom J, Forslund K, Rylander G, Oreland L. Platelet monoamine oxidase activity is related to MAOB intron 13 genotype. J Neural Transm. 2000;107(5):523-530.

131. Gassó P, Mas S, Crescenti A, et al. Lack of association between antipsychotic-induced extrapyramidal symptoms and polymorphisms in dopamine metabolism and transport genes. Psychiatry Res. 2010; 175(1-2):173-175.

132. Nedergaard S, Bolam JP, Greenfield SA. Facilitation of a dendritic calcium conductance by 5 -hydroxytryptamine in the substantia nigra. Nature. 1988;333(6169):174-177.
133. Warren JT Jr, Peacock ML, Rodriguez LC, Fink JK. An MspI polymorphism in the hyman serotonin receptor gene (HTR2): detection by DGGE and RFLP analysis. Hum Mol Genet. 1993;2(3):338.

134. Meltzer HY. An overview of the mechanism of action of clozapine. J Clin Psychiatry. 1994;55 Suppl B:47-52.

135. Segman RH, Heresco-Levy U, Finkel B, et al. Association between the serotonin $2 \mathrm{~A}$ receptor gene and tardive dyskinesia in chronic schizophrenia. Mol Psychiatry. 2001;6(2):225-229.

136. Basile VS, Ozdemir V, Masellis M, et al. Lack of association between serotonin-2A receptor gene (HTR2A) polymorphisms and tardive dyskinesia in schizophrenia. Mol Psychiatry. 2001;6(2):230-234.

137. Lerer B, Segman RH, Tan EC, et al. Combined analysis of 635 patients confirms an age-related association of the serotonin $2 \mathrm{~A}$ receptor gene with tardive dyskinesia and specificity for the non-orofacial subtype. Int J Neuropsychopharmacol. 2005;8(3):411-425.

138. Tan EC, Chong SA, Mahendran R, Dong F, Tan CH. Susceptibility to neuroleptic-induced tardive dyskinesia and the T102C polymorphism in the serotonin type 2A receptor. Biol Psychiatry. 2001;50(2): 144-147.

139. Hsieh CJ, Chen YC, Lai MS, Hong CJ, Chien KL. Genetic variability in serotonin receptor and transporter genes may influence risk for tardive dyskinesia in chronic schizophrenia. Psychiatry Res. 2011;188(1): $175-176$.

140. Reavill C, Kettle A, Holland V, Riley G, Blackburn TP. Attenuation of haloperidol-induced catalepsy by a 5-HT2C receptor antagonist. Br J Pharmacol. 1999;126(3):572-574.

141. Eberle-Wang K, Lucki I, Chesselet MF. A role for the subthalamic nucleus in 5-HT2C-induced oral dyskinesia. Neuroscience. 1996;72(1):117-128

142. Zhang ZJ, Zhang XB, Sha WW, Reynolds GP. Association of a polymorphism in the promoter region of the serotonin 5-HT2C receptor gene with tardive dyskinesia in patients with schizophrenia. Mol Psychiatry. 2002;7(7):670-671.

143. Segman RH, Heresco-Levy U, Finkel B, et al. Association between the serotonin $2 \mathrm{C}$ receptor gene and tardive dyskinesia in chronic schizophrenia: additive contribution of 5-HT2Cser and DRD3gly alleles to susceptibility. Psychopharmacology (Berl). 2000;152(4): 408-413.

144. Segman RH, Lerer B. Age and the relationship of dopamine D3, serotonin $2 \mathrm{C}$ and serotonin $2 \mathrm{~A}$ receptor genes to abnormal involuntary movements in chronic schizophrenia. Mol Psychiatry. 2002;7(2): 137-139.

145. Roth BL, Craigo SC, Choudhary MS, et al. Binding of typical and atypical antipsychotic agents to 5-hydroxytryptamine-6 and 5-hydroxytryptamine-7 receptors. J Pharmacol Exp Ther. 1994;268(3): 1403-1410.

146. Ohmori O, Shinkai T, Hori H, Nakamura J. Genetic association analysis of 5-HT(6) receptor gene polymorphism $(267 \mathrm{C} / \mathrm{T})$ with tardive dyskinesia. Psychiatry Res. 2002;110(2):97-102.

147. Chong SA, Tan EC, Tan CH, Mahendren R, Tay AH, Chua HC. Tardive dyskinesia is not associated with the serotonin gene polymorphism (5-HTTLPR) in Chinese. Am J Med Genet. 2000;96(6):712-715.

148. Naidu PS, Kulkarni SK. Excitatory mechanisms in neuroleptic-induced vacuous chewing movements (VCMs): possible involvement of calcium and nitric oxide. Behav Pharmacol. 2001;12(3):209-216.

149. Shinkai T, Ohmori O, Matsumoto C, Hori H, Kennedy JL, Nakamura J. Genetic association analysis of neuronal nitric oxide synthase gene polymorphism with tardive dyskinesia. Neuromolecular Med. 2004;5(2):163-170.

150. Wang YC, Liou YJ, Liao DL, et al. Association analysis of a neural nitric oxide synthase gene polymorphism and antipsychotics-induced tardive dyskinesia in Chinese schizophrenic patients. J Neural Transm. 2004;111(5):623-629.

151. Thelma BK, Tiwari AK, Deshpande SN, Lerer B, Nimgaonkar VL. Genetic susceptibility to Tardive Dyskinesia in chronic schizophrenia subjects: role of oxidative stress pathway genes. Schizophr Res. 2007;92(1-3):278-279. 
152. Pae CU, Yu HS, Kim JJ, et al. Quinone oxidoreductase (NQO1) gene polymorphism $(609 \mathrm{C} / \mathrm{T})$ may be associated with tardive dyskinesia, but not with the development of schizophrenia. Int $J$ Neuropsychopharmacol. 2004;7(4):495-500.

153. Lee HJ, Kang SG, Choi JE, et al. No Evidence for Association between Tyrosine Hydroxylase Gene Val81Met Polymorphism and Susceptibility to Tardive Dyskinesia in Schizophrenia. Psychiatry Investig. 2009;6(2):108-111.

154. Liou YJ, Wang YC, Chen JY, et al. Association analysis of polymorphisms in the $\mathrm{N}$-methyl-D-aspartate (NMDA) receptor subunit 2B (GRIN2B) gene and tardive dyskinesia in schizophrenia. Psychiatry Res. 2007;153(3):271-275.

155. Lee HJ, Kang SG, Paik JW, et al. No evidence for an association between $\mathrm{G}$ protein beta3 subunit gene $\mathrm{C} 825 \mathrm{~T}$ polymorphism and tardive dyskinesia in schizophrenia. Hum Psychopharmacol. 2007;22(8):501-504.

156. Fernández-Ruiz J. The endocannabinoid system as a target for the treatment of motor dysfunction. Br J Pharmacol. 2009;156(7): 1029-1040.

157. Ipsen M, Zhang Y, Dragsted N, Han C, Mulvany MJ. The antipsychotic drug sertindole is a specific inhibitor of alpha1 A-adrenoceptors in rat mesenteric small arteries. Eur J Pharmacol. 1997;336(1):29-35.

158. Svensson TH. Alpha-adrenoceptor modulation hypothesis of antipsychotic atypicality. Prog Neuropsychopharmacol Biol Psychiatry. 2003;27(7):1145-1158.
159. Beaulieu JM, Tirotta E, Sotnikova TD, et al. Regulation of Akt signaling by D2 and D3 dopamine receptors in vivo. J Neurosci. 2007;27(4): 881-885.

160. Kim D, Chung J. Akt: versatile mediator of cell survival and beyond. J Biochem Mol Biol. 2002;35(1):106-115.

161. Zai CC, Romano-Silva MA, Hwang R, et al. Genetic study of eight AKT1 gene polymorphisms and their interaction with DRD2 gene polymorphisms in tardive dyskinesia. Schizophr Res. 2008;106(2-3): 248-252.

162. Bigos KL, Bies RR, Pollock BG et al. Genetic variation in CYP3A43 explains racial difference in clanzapine clearance. Mol Physciatry. 2011;16(6):620-625.

163. Lovlie R, Daly AK, Matre GE et al. Polymorphisms in CYP2D6 duplication-negative individuals with the ultrarapid metabolizer phenotype a, role for the CYP2D6*35 allele in ultrarapid metabolsim? Pharmacogentics. 2011;11(1):45-55.

164. Weslind-Johnsson A, Hermann R, Hvennemeyer A et al. identification and characcter of CYP3A4*20, a novel rare CYP3A4 allele without functional activity. Clin Pharmacol Ther. 2006;79(4):339-349.

165. Gaedigk A, Bradfor LD, Marcuci KA et al. Unique CYP2D6 activity distribution and genotype-phenotype discordance in black Americans. Clin Pharmacol Ther. 2002:72(1):76-89.

166. Zhou SF, Liu Jp, Chowbay B. Polymorphism of human cytochrome P450 enzymes and its clinical impact. Drug Metab Rev. 2009;41(2):89-295.
Pharmacogenomics and Personalized Medicine

\section{Publish your work in this journal}

Pharmacogenomics and Personalized Medicine is an international, peerreviewed, open access journal characterizing the influence of genotype on pharmacology leading to the development of personalized treatment programs and individualized drug selection for improved safety, efficacy and sustainability. This journal is indexed on the American Chemical

\section{Dovepress}

Society's Chemical Abstracts Service (CAS). The manuscript management system is completely online and includes a very quick and fair peer-review system, which is all easy to use. Visit http://www.dovepress. com/testimonials.php to read real quotes from published authors. 